\title{
POSSIBLE CONTRIBUTION OF SOME ADIPOKINES ON TYPE II DIABETES IN OBESE AND NON-OBESE ADULT MALE RATS
}

\author{
By \\ Hamed Mohamed Osman, Ahmed Desoky Badawy ${ }^{(1)}$, \\ Mohamed El-Sayed Abdelfatah and Mohamed Fekry Farag ${ }^{(2)}$ \\ Medical Physiology Departments, Al-Azhar Faculty of Medicine, \\ October $6^{\text {th }}$ Faculty Of Medicine ${ }^{(1)}$, and Armed Forces College of Medicine ${ }^{(2)}$
}

\begin{abstract}
Background: Type 2 diabetes results from a complex interplay between genetic and environmental factors. Overweight/obesity is a major risk factor for type 2 diabetes. Objective: Examining the changes in leptin, adiponectin and resistin levels in obese and non-obese rats with type 2 diabetes mellitus, and the effects on body weight, BMI, insulin resistance, $\mathrm{HbAlc}$ and fasting blood sugar. Materials and methods: Forty adult male albino rats of local strain were chosen as an animal model for this study. They were divided into normal control, control obese, diabetes mellitus and diabetes mellitus obese rats. Rats were rendered diabetic by a single intraperitoneal injection of STZ (40mg/kg B.W) that successfully induced type 2 diabetes. The high fat diet was used to induce obesity. It was prepared by increasing the fat content of diet to $11-12 \%$. At the end of the experimental period, rats were weighed and BMI was calculated. The rats were anesthetized, blood samples were collected, and the separated plasma was stored at -20 ?C for biochemical assays. Results: Regarding plasma leptin and resistin levels, all groups showed a significant increase as compared with control. There was a significant decrease in plasma adiponectin levels in all groups as compared with control group. There was a significant increase in plasma L/A ratio in all groups as compared with control group. Conclusion: The decrease in adiponectin and the increase in resistin and leptin levels inplasma could be attributed to hyperglycemia and the increased insulin resistance observed in obese, diabetic and diabetic obese rats.
\end{abstract}

Key words: Diabetes mellitus, Obesity, Leptin, Adiponectin, Resistin.

\section{INTRODUCTION}

Type 2 diabetes mellitus is a complex metabolic disorder essentially characterized by alterations in lipid metabolism, insulin resistance and pancreatic $\beta$-cell dysfunction (Gheibi et al., 2017).

Obesity is closely related to insulin resistance, glucose intolerance and type 2 diabetes, and it has been suggested that adipocyte derived hormones are involved in the pathophysiology linking obesity to these conditions. Apart from its role in storage and release of fatty acids, white adipose tissue is a major secretory organ for many proteins, referred to as 'adipokines'. These include proinflammatory cytokines, chemokines and acute-phase proteins as well as adiponectin and leptin (Spite et al, 2014). 
Adiponectin, produced in adipocytes, improves insulin sensitivity in muscle and liver by enhancing fatty acid oxidation (Efeyan et al., 2015). The decrease in adiponectin secretion in obesity is believed to be caused by the inhibitory action on adiponectin gene transcription of inflammatory molecules secreted from hypertrophic adipocytes (Hajer et al., 2008).

Leptin is a peptide hormone mainly secreted by white adipose tissue (S?inz et al., 2015). It acts on the hypothalamus, leading to decreased appetite and increased energy expenditure, thereby regulating body weight. Furthermore, leptin has a number of other activities, including regulation of endocrine function, reproduction and immunity (Esser et al., 2014).

Resistin is a cysteine-rich polypeptide that is expressed at relatively lower levels in human adipocytes but higher levels in macrophages. Initial experimental studies in rodents pointed to an important role of resistin as a mediator of obesityassociated insulin resistance. (Santilli et al., 2016).

The present work aimed to examine the changes in plasma levels of leptin, adiponectin and resistin in obese and nonobese rats with type 2 diabetes mellitus, and the associated effects of these changes on body weight, BMI, insulin resistance, HbA1c and fasting blood sugar.

\section{MATERIALS AND METHODS}

Animals: Forty adult male, albino rats of local strain were chosen as an animal model for this study. Their weights ranged between 140 and 145 grams at the beginning of the study. They were kept in animal house of Faculty of Medicine, Cairo University. Animals were handled according to the guidelines for the use and care of laboratory animals approved by Faculty of Medicine, Cairo University, research ethics committee; under constant condition of temperature, ventilation, humidity, light with free access to water. Animals were kept in cages ( 30 X 30 X 20 $\mathrm{cm}-4$ rats per cage), and were fed with control diet in regular meals at 8 a.m., daily in the form of milk, bread, cereals and vegetables for 2 weeks for adaptation. Rats included in the present study were allocated into four equal groups: Group I (Control normal group) received control diet formula, Group II (Control obese group) were fed high fat diet formula, Group III (Diabetes mellitus group) where rats in this group were on control diet formula and received single intraperitoneal injection of STZ in a dose of $40 \mathrm{mg} / \mathrm{kg}$, Group IV (Diabetes mellitus obese group) received high fat diet formula for 2 weeks, then received single intraperitoneal injection of STZ in a dose of $40 \mathrm{mg} / \mathrm{kg}$.

Methods: Streptozotocin (Sigma, USA) was used for induction of diabetes. This was prepared by dissolving STZ powder in $0.05 \mathrm{M}$ citrate buffer to reach a final concentration of $2000 \mathrm{mg} / \mathrm{dl}$. Rats were injected with a dose equivalent to 40 $\mathrm{mg} / \mathrm{kg}$ body weight (Yoshino et al., 1992). High fat diet used to induce obesity (Woods et al., 2003). It was prepared by increasing the fat content of diet to 11$12 \%$. At the end of the experimental period which was one month, rats were weighed and BMI was calculated as follows: 


$$
\mathrm{BMI}=\frac{\text { Body weight }(\mathrm{g})}{\text { Square length }\left(\mathrm{cm}^{2}\right)}
$$

The body weight was determined (to the nearest $0.01 \mathrm{~g}$ ), and the length of the rat was measured as the distance $(\mathrm{cm})$ between the nose of the rat and the anus (naso-anal length).

Rats were injected intraperitoneally with 1000 IU heparin sodium (Nile Co.), and half an hour later, the rats were anesthetized by i.p injection of thiopental sodium (Sandoz, Austria) in a dose of $40 \mathrm{mg} / \mathrm{kg}$ body weight. The anesthetized rat was fixed on the rat dissecting board and the naso-anal length was recorded (needed to calculate the BMI). A midline incision was made, and the abdominal aorta was exposed and cannulated with polyethylene catheter for blood sampling. Specific sample of fresh blood was taken to determine HbA1c and the rest of blood samples collected were then centrifuged at $3000 \mathrm{rpm}$ for 10 minutes and the separated plasma was pipetted and stored at -20?C for biochemical assays, i.e. plasma glucose, insulin, adiponectin, leptin and resistin.

All statistical data, statistical significance and correlation study were performed by using SPSS (statistical program for social science) statistical package (SPSS Inc.) version 25. Values of the measured parameters were expressed as mean value \pm standard error of mean (SEM), and the differences and significances were verified by one-way ANOVA followed by the Fisher's least significant difference (LSD) post hoc test. P-values $\leq 0.05$ were considered statistically significant.

\section{RESULTS}

The results encountered in the present study reflected the changes in plasma leptin, plasma adiponectin, plasma resistin, L/A ratio, plasma glucose, plasma insulin, $\mathrm{HbA1c}$, insulin resistance, body weight and body mass index in group I (control group), group II (control obese group), group III (diabetes mellitus group), and group IV (diabetes mellitus obese group).

\section{Changes in body weight and body mass index ( BMI) (Table 1):}

In group $\mathrm{I}$, the mean \pm SEM of body weight and BMI were $148.1 \pm 0.85 \mathrm{~g}$ and $0.57 \pm 0.016 \mathrm{~g} / \mathrm{cm}^{2}$ respectively. In group II, the mean \pm SEM of body weight and BMI were $246 \pm 1.7 \mathrm{~g}$ and $0.94 \pm 0.029$ $\mathrm{g} / \mathrm{cm}^{2}$ respectively. There was a significant increase in body weight and BMI in group II when compared with group I. In group III, the mean \pm SEM of body weight and BMI were $148.9 \pm 0.85 \mathrm{~g}$ and $0.54 \pm 0.016 \mathrm{~g} / \mathrm{cm}^{2}$ respectively. There was no significant difference in body weight or BMI in group III when compared with group I. There was a significant decrease in body weight and BMI in group III when compared with group II. In group IV, the mean \pm SEM of body weight and BMI were 246 $\pm 1.7 \mathrm{~g}$ and $0.97 \pm 0.027 \mathrm{~g} / \mathrm{cm}^{2}$ respectively. There was no significant difference in body weight or BMI in group IV when compared with group II. There was a significant increase in body weight and BMI in group IV when compared with group III. 
Table (1): Changes of body weight and body mass index in all groups.

\begin{tabular}{|l|c|c|c|c|}
\hline \multicolumn{1}{|c|}{ Groups } & Group (I) & Group (II) & Group (III) & Group (IV) \\
\hline $\begin{array}{l}\text { Parameters } \\
\text { Body weight }\end{array}$ & $148.1 \pm 0.85$ & $246 \pm 1.7$ & $148.9 \pm 0.85$ & $246 \pm 1.7$ \\
& & $\mathbf{P}<\mathbf{0 . 0 5} * \mathbf{a}$ & $\mathbf{P}>\mathbf{0 . 0 5} \# \mathbf{a}$ & $\mathbf{P}<\mathbf{0 . 0 5} * \mathbf{a}$ \\
& & $\mathbf{P}<\mathbf{0 . 0 5} * \mathbf{b}$ & $\mathbf{P . 0 5} \# \mathbf{a}$ \\
& & & & $\mathbf{P}<\mathbf{0 . 0 5} * \mathbf{c}$ \\
\hline $\mathrm{BMI}$ \\
$\left(\mathrm{g} / \mathrm{cm}^{2}\right)$
\end{tabular}

a : compared with group I

b : compared with group II

c : compared with group III

* : significant

\# : insignificant

Changes in plasma glucose, plasma insulin, $\mathrm{Hb}$ A1c and insulin resistance (Table 2):

In group I, the mean \pm SEM of plasma glucose, plasma insulin, HbA1c and insulin resistance were $5.38 \pm 0.24$ $\mathrm{mmol} / \mathrm{l}, \quad 9.34 \pm 0.42 \mathrm{mIU} / \mathrm{l}, \quad 4.61 \pm 0.2 \%$ and $2.23 \pm 0.16 \mathrm{mmolmIU} / \mathrm{I}^{2}$ respectively. In group II, the mean \pm SEM of plasma glucose, plasma insulin, HbA1c and insulin resistance were $11.18 \pm 1.11$ $\mathrm{mmol} / \mathrm{l}, 13.78 \pm 0.64 \mathrm{mIU} / \mathrm{l}, 5.45 \pm 0.25$ $\%$ and $6.53 \pm 0.41$ mmolmIU/ ${ }^{2}$ respectively. There was a significant increase in plasma glucose, plasma insulin and insulin resistance in group II when compared to group I. There was no significant difference in HbA1c in group II when compared with group I. In group III, the mean \pm SEM of plasma glucose, plasma insulin, HbA1c and insulin resistance were $10.88 \pm 0.65 \mathrm{mmol} / \mathrm{l}$,
$14.04 \pm 0.7 \mathrm{mIU} / \mathrm{l}, 7.37 \pm 0.43 \%$ and $6.73 \pm 0.43 \mathrm{mmolmIU} / \mathrm{l}^{2}$ respectively. There was a significant increase in plasma glucose, plasma insulin, HbA1c and insulin resistance in group III when compared to group I. There was no significant difference in plasma glucose, plasma insulin and insulin resistance in group III when compared with group II. There was a significant increase in HbA1c in group III when compared to group II. In group IV, the mean \pm SEM of plasma glucose, plasma insulin, HbA1c and insulin resistance were $14.77 \pm 1.1$ $\mathrm{mmol} / \mathrm{l}, 17.61 \pm 0.97 \mathrm{mIU} / \mathrm{l}, 8.73 \pm 0.54 \%$ and $11.18 \pm 0.49 \mathrm{mmolmIU} / \mathrm{l}^{2}$ respectively. There was a significant increase in plasma glucose, plasma insulin, HbA1c and insulin resistance in group IV when compared to group II and when compared to group III. 
POSSIBLE CONTRIBUTION OF SOME ADIPOKINES ON TYPE II DIABETES...

Table (2): Changes of fasting plasma glucose, plasma insulin, HBA1c and insulin resistance in all groups.

\begin{tabular}{|c|c|c|c|c|}
\hline Parameters & Group (I) & Group (II) & Group (III) & Group (IV) \\
\hline $\begin{array}{l}\text { Plasma glucose } \\
(\mathrm{mmol} / \mathrm{l})\end{array}$ & $5.38 \pm 0.24$ & $\begin{array}{c}11.18 \pm 1.11 \\
\mathbf{P}<\mathbf{0 . 0 5} * \mathbf{a}\end{array}$ & $\begin{array}{c}10.88 \pm 0.65 \\
\mathbf{P}<\mathbf{0 . 0 5} * \mathbf{a} \\
\mathbf{P}>\mathbf{0 . 0 5} \# \mathbf{b}\end{array}$ & $\begin{array}{c}14.77 \pm 1.1 \\
\mathbf{P}<\mathbf{0 . 0 5} * \mathbf{a} \\
\mathbf{P}<\mathbf{0 . 0 5} * \mathbf{b} \\
\mathbf{P}<\mathbf{0 . 0 5} * \mathbf{c}\end{array}$ \\
\hline $\begin{array}{l}\text { Plasma insulin } \\
(\mathrm{mIU} / \mathrm{l})\end{array}$ & $9.34 \pm 0.42$ & $\begin{array}{c}13.78 \pm 0.64 \\
\mathbf{P}<\mathbf{0 . 0 5} * \mathbf{a}\end{array}$ & $\begin{array}{l}14.04 \pm 0.7 \\
\mathbf{P}<\mathbf{0 . 0 5} * \mathbf{a} \\
\mathbf{P}>\mathbf{0 . 0 5} \# \mathbf{b}\end{array}$ & $\begin{array}{c}17.61 \pm 0.97 \\
\mathbf{P}<\mathbf{0 . 0 5} * \mathbf{a} \\
\mathbf{P}<\mathbf{0 . 0 5} * \mathbf{b} \\
\mathbf{P}<\mathbf{0 . 0 5} * \mathbf{c}\end{array}$ \\
\hline $\begin{array}{l}\text { HbA1c } \\
(\%)\end{array}$ & $4.61 \pm 0.2$ & $\begin{array}{c}5.45 \pm 0.25 \\
\mathbf{P}>\mathbf{0 . 0 5} \\
\mathbf{P}>\mathbf{0 . 0 5} \#^{\mathbf{a}}\end{array}$ & $\begin{array}{l}7.37 \pm 0.43 \\
\mathbf{P}<\mathbf{0 . 0 5} * \mathbf{a} \\
\mathbf{P}<\mathbf{0 . 0 5} * \mathbf{b}\end{array}$ & $\begin{array}{l}8.73 \pm 0.54 \\
\mathbf{P}<\mathbf{0 . 0 5} * \mathbf{a} \\
\mathbf{P}<\mathbf{0 . 0 5} * \mathbf{b} \\
\mathbf{P}<\mathbf{0 . 0 5} * \mathbf{c}\end{array}$ \\
\hline $\begin{array}{l}\text { Insulin } \\
\text { resistance } \\
\left(\mathrm{mmolmIU} / 1^{2}\right)\end{array}$ & $2.23 \pm 0.16$ & $\begin{array}{l}6.53 \pm 0.41 \\
\mathbf{P}<\mathbf{0 . 0 5} * \mathbf{a}\end{array}$ & $\begin{array}{l}6.73 \pm 0.43 \\
\mathbf{P}<\mathbf{0 . 0 5} * \mathbf{a} \\
\mathbf{P}>\mathbf{0 . 0 5} \# \mathbf{b}\end{array}$ & $\begin{array}{l}11.18 \pm 0.49 \\
\mathbf{P}<\mathbf{0 . 0 5} * \mathbf{a} \\
\mathbf{P}<\mathbf{0 . 0 5} * \mathbf{b} \\
\mathbf{P}<\mathbf{0 . 0 5} * \mathbf{c}\end{array}$ \\
\hline
\end{tabular}

a : compared with group I

b : compared with group II

c : compared with group III

* : significant

\# : insignificant

Changes in plasma leptin, plasma adiponectin, plasma resistin and $\mathrm{L} / \mathrm{A}$ ratio (Table 3):

In group $\mathrm{I}$, the mean \pm SEM of plasma leptin, adiponectin, resistin and $\mathrm{L} / \mathrm{A}$ ratio were $85.64 \pm 4.08 \mathrm{pg} / \mathrm{ml}, \quad 16.51 \pm 0.83$ $\mathrm{ng} / \mathrm{ml}, \quad 2.42 \pm 0.14 \mathrm{ng} / \mathrm{ml}$ and $5.34 \pm 0.45$ respectively. In group II, the mean \pm SEM of plasma leptin, adiponectin, resistin and L/A ratio were $175.58 \pm 5.89 \mathrm{pg} / \mathrm{ml}$, $8.93 \pm 0.65 \mathrm{ng} / \mathrm{ml}, \quad 5.89 \pm 0.63 \mathrm{ng} / \mathrm{ml}$ and $20.77 \pm 1.84$ respectively. There was a significant increase in plasma leptin, adiponectin, resistin and L/A ratio in group II when compared with group I. In group III, the mean \pm SEM of plasma leptin, adiponectin resistin and L/A ratio were $187.69 \pm 4.43 \mathrm{pg} / \mathrm{ml}, 9.39 \pm 1.02$ $\mathrm{ng} / \mathrm{ml}, \quad 6.7 \pm 0.58 \mathrm{ng} / \mathrm{ml}$ and $22.16 \pm 2.32$ respectively. There was no significant difference in plasma leptin, adiponectin, resistin and L/A ratio in group III when compared with group II. ButThere was a significant increase in plasma leptin, adiponectin, resistin and L/A ratio in group III when compared with group I. In group IV, the mean \pm SEM of plasma leptin, adiponectin, resistin and L/A ratio were $275.41 \pm 24.99 \mathrm{pg} / \mathrm{ml}, 7.45 \pm 0.84$ $\mathrm{ng} / \mathrm{ml}, 9.93 \pm 0.43 \mathrm{ng} / \mathrm{ml}$ and $45.33 \pm 9.79$ 
respec-tively. There was significant increase in plasma leptin, resistinand L/A ratio in group IV when compared with group II and when compared to group III.
There was no significant difference in plasma adiponectin in group IV when compared with group II and when compared to group III.

Table (3): Changes of plasma leptin, adiponectin, resistin levels and L/A ratio in all groups.

\begin{tabular}{|c|c|c|c|c|}
\hline Parameters & Group (I) & Group (II) & Group (III) & Group (IV) \\
\hline $\begin{array}{l}\text { Plasma leptin } \\
(\mathrm{pg} / \mathrm{ml})\end{array}$ & $85.64 \pm 4.08$ & $\begin{array}{c}175.58 \pm 5.89 \\
\mathbf{P}<\mathbf{0 . 0 5} * \mathbf{a}\end{array}$ & $\begin{array}{c}187.69 \pm \\
4.43 \\
\mathbf{P}<\mathbf{0 . 0 5} * \mathbf{a} \\
\mathbf{P}>\mathbf{0 . 0 5} \# \mathbf{b}\end{array}$ & $\begin{array}{c}275.41 \pm 24.99 \\
\mathbf{P}<\mathbf{0 . 0 5} * \mathbf{a} \\
\mathbf{P}<\mathbf{0 . 0 5} * * \mathbf{b} \\
\mathbf{P}<\mathbf{0 . 0 5} * * * \mathbf{c}\end{array}$ \\
\hline $\begin{array}{l}\text { Plasma adiponectin } \\
(\mathrm{ng} / \mathrm{ml})\end{array}$ & $16.51 \pm 0.83$ & $\begin{array}{c}8.93 \pm 0.65 \\
\mathbf{P}<\mathbf{0 . 0 5} * \mathbf{a}\end{array}$ & $\begin{array}{c}9.39 \pm 1.02 \\
\mathbf{P}<\mathbf{0 . 0 5} * \mathbf{a} \\
\mathbf{P}>\mathbf{0 . 0 5} \# \mathbf{b}\end{array}$ & $\begin{array}{c}7.45 \pm 0.84 \\
\mathbf{P}<\mathbf{0 . 0 5} * \mathbf{a} \\
\mathbf{P}>\mathbf{0 . 0 5} \# \mathbf{b} \\
\mathbf{P}>\mathbf{0 . 0 5} \# \mathbf{c}\end{array}$ \\
\hline $\begin{array}{l}\text { Plasma resistin } \\
(\mathrm{ng} / \mathrm{ml})\end{array}$ & $2.42 \pm 0.14$ & $\begin{array}{l}5.89 \pm 0.7 r \\
\mathbf{P}<\mathbf{0 . 0 5} * \mathbf{a}\end{array}$ & $\begin{array}{c}6.7 \pm 0.58 \\
\mathbf{P}<\mathbf{0 . 0 5} * \mathbf{a} \\
\mathbf{P}>\mathbf{0 . 0 5} \# \mathbf{b}\end{array}$ & $\begin{array}{c}9.93 \pm \cdot . \varepsilon r \\
\mathbf{P}<\mathbf{0 . 0 5} * \mathbf{a} \\
\mathbf{P}<\mathbf{0 . 0 5} * * \mathbf{b} \\
\mathbf{P}<\mathbf{0 . 0 5} * * * \mathbf{c}\end{array}$ \\
\hline L/A ratio & $5.34 \pm 0.45$ & $\begin{array}{l}20.77 \pm 1.84 \\
\mathbf{P}<\mathbf{0 . 0 5} * \mathbf{a}\end{array}$ & $\begin{array}{l}22.16 \pm 2.32 \\
\mathbf{P}<\mathbf{0 . 0 5} * \mathbf{a} \\
\mathbf{P}>\mathbf{0 . 0 5} \# \mathbf{b}\end{array}$ & $\begin{array}{c}45.33 \pm 9.79 \\
\mathbf{P}<\mathbf{0 . 0 5} * \mathbf{a} \\
\mathbf{P}<\mathbf{0 . 0 5} * * \mathbf{b} \\
\mathbf{P}<\mathbf{0 . 0 5} * * * \mathbf{c}\end{array}$ \\
\hline
\end{tabular}

a : compared with group I

b : compared with group II

c : compared with group III

* : significant

\# : insignificant

\section{DISCUSSION}

The results of the present study showed that rats fed high fat diet developed obesity; which is indicated by the significant increase in body weight and BMI in rats in control obese group (group II) and diabetes mellitus obese group (group IV). Consumption of high fat, high-calorie diets leads to hyperphagia via a number of different mechanisms, including impairment of the lipid-induced activation of the vagal afferent pathway by which information about ingested nutrients reaches the CNS and influence both GIT function and feeding behavior (Sampath et al., 2017). 
The results of the present study showed that rats injected with STZ, at a dose of 40 $\mathrm{mg} / \mathrm{kg}$, developed type 2 diabetes mellitus; which was indicated by the significant increase in fasting plasma glucose levels, fasting plasma insulin levels, HOMA-IR and blood HbA1c levels in diabetes mellitus group (group III) and diabetes mellitus obese group (group IV). This probably resulted from the action of STZ on pancreatic $\beta$ cells by causing partial damage and occurrence of insulin resistance in peripheral tissues especially skeletal muscles regarding their importance in glucose homeostasis (Podell et al., 2017).

The results of the present study also showed that there was a significant increase in plasma leptin levels in group II (control obese) as compared with group I (control). This could be due to the increase in body fat that secretes more leptin, also due to the relative leptin resistance developed. The correlation studies showed that there was a significant positive correlation between plasma leptin level and BMI. Münzberg and Morrison (2015) stated that hyper-leptinemia induced by a high-fat diet causes leptin resistance within pro-opiomelanocortin (POMC) and Agouti-related protein (AGRP) expressing neurons of the hypothalamus. Because activation of pSTAT3 is diminished in these neurons, by excluding the signalling defect, must be located upstream of STAT3 phosphorylation.

There was also a significant increase in plasma leptin levels in group III (diabetes mellitus) as compared with group I (control). This could be due to the elevated fasting plasma insulin level observed in group III of the present study, with consequent increase in plasma leptin levels. This was in agreement with Kocot et al. (2017) who found a signi?cant correlation between leptin and insulin. Insulin increases the translation of leptin mRNA. Insulin may increase the translational efficiency of leptin mRNA by post-translational modification or de novo synthesis of a factor, or factors, that interact with the leptin UTRs (Burnett et al., 2017).

In the diabetes mellitus obese group (group IV), current results showed a significant increase in plasma leptin levels as compared with control obese group (group II) and diabetes mellitus group (group III). This could be explained by the cumulative effect of obesity and diabetes on elevating the plasma leptin level.

Regarding plasma adiponectin levels, the present results showed a significant decrease in plasma adiponectin levels in groups II (control obese) as compared with group I (control). The correlation studies showed that there was a significant negative correlation between plasma adiponectin level and BMI. That could be explained by the fact that adiponectin plasma levels are inversely proportional to body fat content. Hypoadiponectinemia is known to be the molecular link between obesity and insulin-resistance, observed in metabolic syndrome (Adya et al., 2015).

Moreover, the present results showed a significant decrease in plasma adiponectin levels in group III (Diabetes mellitus) as compared with group I (control). Bergmark et al. (2017) reported that plasma levels of adiponectin (ADN) significantly decrease in patients with type 2 DM. Epidemiologic studies reveal that 
ADN gene single nucleotide polymorphisms are related to the future development of type $2 \mathrm{DM}$ and metabolic syndrome (Momin et al., 2017).

There was a significant increase in plasma resistin levels in control obese group (groups II) as compared with control group (group I). The correlation studies showed that there was a positive significant correlation between plasma resistin level and BMI. Hannan and Culligan (2015) reported that plasma resistin levels positively correlate with body weight across several mouse models of obesity. In rodents, plasma resistin levels increase in diet-induced and genetic forms of obesity. There was also a significant increase in plasma resistin levels in group III as compared with group I.

Resistin contributes to insulin resistance by 5' AMP-activated protein kinase (AMPK)-dependent and AMPKindependent suppressor of cytokine signaling-3 (SOCS-3) signaling pathways (Liu et al., 2014). The AMPK pathway 'senses' cellular energy status and is activated by a decrease in the ATP-toAMP ratio, which then activates ATPproducing pathways and inhibits ATPconsuming pathways, including decreasing gluconeogenesis via glucose-6phosphatase and PEPCK, increasing fatty acid $\beta$-oxidation, decreasing fatty acid esterification of triglycerides and inhibiting de novo fatty acid synthesis via acetylCoA carboxylase-1 (ACC1) (Romacho et al., 2014). There was a significant increase in plasma resistin levels in group IV as compared with groups II and III.
Since obesity and T2DM are both associated with chronic inflammation; and resistin is mainly produced by macrophages in humans, it is possible that hyper-resistinemia is a contributing factor to these pathophysiological states. Generated transgenic mice expressing human resistin via a macrophage promoter and bred them with resistin knockout mice developed inflammation and insulin resistance, demonstrating that human resistin may link inflammatory responses and glucose homeostasis (Menzaghi et al., 2013).

\section{CONCLUSION}

The decrease in adiponectin and the increase in resistin and leptin could be attributed to hyperglycemia and the increased insulin resistance observed in obese, diabetic and diabetic obese rats.

\section{REFERENCES}

1. Adya R., Tan B. and Randeva H. (2015): Differential effects of leptin and adiponectin in endothelial angiogenesis. Journal of diabetes research, 15(1): 11-12.

2. Bergmark B., Cannon c., White W., Jarolim P., Liu Y., Bonaca M. and Morrow D. (2017): Baseline adiponectin concentration and clinical outcomes among patients with diabetes and recent acutecoronary syndrome in the EXAMINE trial. Diabetes, Obesity and Metabolism, 19(7): 962-969.

3. Burnett L., Skowronski A., Rausch R., LeDuc A. and Leibel L. (2017): Determination of the half-life of circulating leptin in the mouse. International Journal of Obesity, 41(3): 355359.

4. Efeyan A., Comb W. C. and Sabatini D.M. (2015): Nutrient-sensing mechanisms and pathways. Nature, 517(7534): 302-313.

5. Esser N., Legrand-Poels S., Piette J., Scheen A. J. and Paquot N. (2014): Inflammation as a link between obesity, metabolic syndrome and 
type 2 diabetes. Diabetes research and clinical practice, 105(2): 141-150.

6. Gheibi S. , Bakhtiarzadeh F., Jeddi S., Farrokhfall K., Zardooz H. and Ghasemi A. (2017): Nitrite increases glucose-stimulated insulin secretion and islet insulin content in obese type 2 diabetic male rats. Nitric Oxide, 64: 39-51.

7. Hajer G.R., vanHaeften T.W. and Visseren F.L. (2008): Adipose tissue dysfunction in obesity, diabetes, and vascular diseases. Eur Heart J., 2959-2971.

8. Hannan F. and Culligan K.G. (2015): Human resistin and the RELM of Inflammation in diabesity. Diabetol Metab Syndr., 7: 1-11.

9. Kocot J., Dziemidok P., Kielczykowska M., Hordyjewska A., Szcześniak G. and Musik I. (2017): Adipokine Profile in Patients with Type 2 Diabetes Depends on Degree of Obesity. International Medical Journal of Experimental and Clinical Research, 23: 4995-4998.

10. Liu C.W., Yang S.Y., Lin C.K., Liu H.S., Ho L.T. and Wu L.Y. (2014): The forkhead transcription factor FOXO1 stimulates the expression of the adipocyte resistin gene. Gen Comp Endocrinol., 196: 41-51.

11. Menzaghi C., Bacci S., Salvemini L., Mendonca C., Palladino G., Fontana A., De Bonis C., Marucci A., Goheen E., Prudente S., Morini E., Rizza S., Kanagaki A., Fini G., Mangiacotti D., Federici M., De Cosmo S., Pellegrini F., Doria A. and Trischitta V. (2013): Serum resistin, cardiovascular disease and all-cause mortality in patients with type 2 diabetes. PLoS One, 8: e64729.

12. Momin A., Bankar M. and Bhoite G. (2017): Association of single nucleotide polymorphisms of adiponectin gene with type 2 diabetes mellitus, and their influence on cardiovascular risk markers. Indian Journal of Clinical Biochemistry, 32(1): 53-60.

13. Münzberg H. and Morrison C. D (2015): "Structure, production and signal ingofleptin," Metabolism: Clinical and Experimental, 64(1): 13-23.

14. Podell B.K., Ackart D.F., Richardson M.A., DiLisio J.E., Pulford B. and Basaraba R.J.
(2017): A model of type 2 diabetes in the guinea pig using sequential diet-induced glucose intolerance and streptozotocin treatment. Dis. Model Mech., 10 (2): 151-162.

15. Romacho T., Elsen M., R?hrborn D. and Eckel J. (2014): Adipose tissue and its role in organ crosstalk. Acta Physiol., 210: 733-753.

16. S?inz N., Barrenetxe J., Moreno-Aliaga M. J. and Mart?ez J. A. (2015): Leptin resistance and diet-induced obesity: central and peripheral actions of leptin. MetabolismClinical and Experimental, 64(1): 35-46.

17. Sampath C., Rashid M.R., Sang S. and Ahmedna M. (2017): Green tea epigallocatechin 3gallate alleviates hyperglycemia and reduces advanced glycation end products via nrf 2 pathway in mice with high fat diet-induced obesity. Biomed. Pharmacother., 87: 73-81

18. Santilli F., Liani R., Di Fulvio P., Formoso G., Simeone P., Tripaldi R. and Dav? G. (2016). Increased circulating resistin is associated with insulin resistance, oxidative stress and platelet activation in type 2 diabetes mellitus. Thrombosis and Haemostasis, 116(12): 1089-1099.

19. Spite M., Clària J. and Serhan C. N. (2014): Resolvins, specialized proresolving lipid mediators, and their potential roles in metabolic diseases. Cell metabolism, 19(1): 21-36.

20. Woods S.C., Seeley R.J., Rushing P.A., D'Alessio D. and Tso P. (2003): A controlled high-fat diet induces an obese syndrome in rats. J. Nutr., 133: 1081-1087.

21. Yoshino G., Fatsushita M., Maeda E., Naka Y., Nagata K., Mosita M.M., Mats K., Kazumi T. and Kasuga M. (1992): Effects of long-term insulin deficiency and insulin treatment on the composition of triglyceriderich lipoproteins and triglyceride turnover in rats. Atherosclerosis, 2(3): 243-30. 


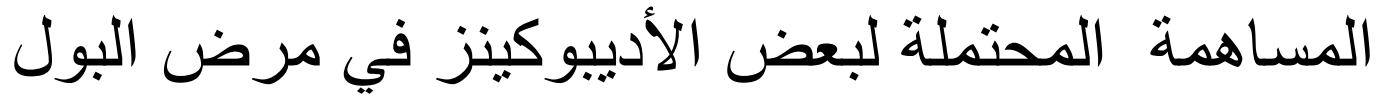

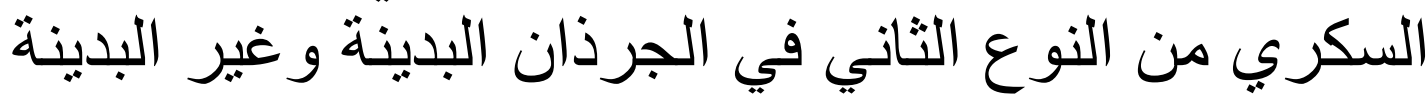

حامد محمد عثمان ـ أحمد دسوقي بدوي(') ـ محمد السيد عبد الفتاح ـ محمد فكري فرج(؟) أقسام الفسيولوجيا الطبية ـ بكليات الطب- جامعة الأزهر و جامعة ج أكتوبر(1) وكلية الطب بالقوات المسلحة(؟)

خلقيـة البحث: ينتج مـرض البول السكري مـن النوع الثاني عن تفاعل معقد بين العو امل الجينيـة

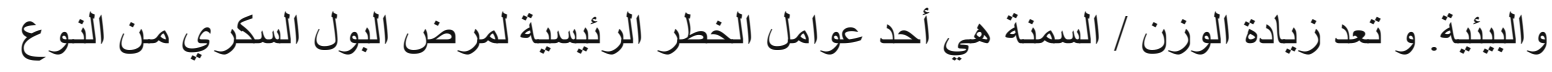
الثاني.

الهـف من البحث: در اسـة التغيرات في مستويات الليبتين ،الأديبونيكتين و الريزيستين في الجرذان

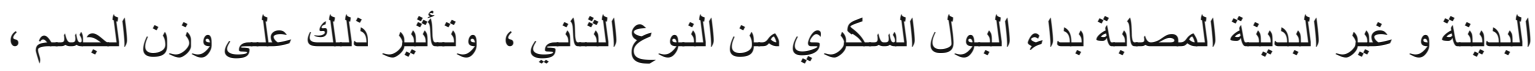
و مؤشر كتلة الجسم ، ومقاومة الأنسولين وسكر الام الصائه الئه

مواد و طرق البحث: تم إختبار أربعين من ذكور الجرذان البيضاء من سـلالة محلية كنموذج حيو اني

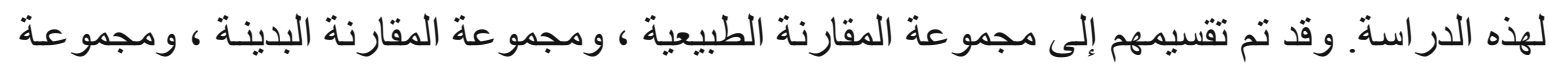
الجرذان المصابة بالبول السكري ، ومجمو عة الجرذان البدينة المصابة بالبول السكري. و و قد تم إعطاء

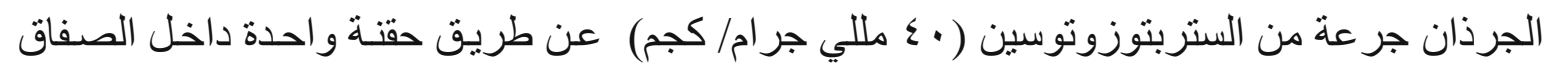

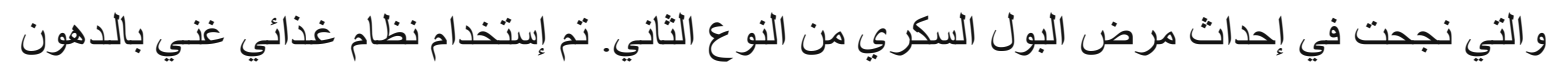

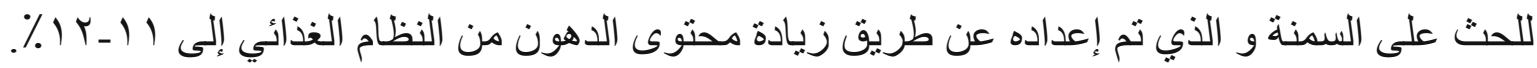
وفي نهاية الفترة التجريبية تم وزن الجرذان وحساب مؤشر كتلة الجسم ،كما تم تخدير الجرذان وجمع

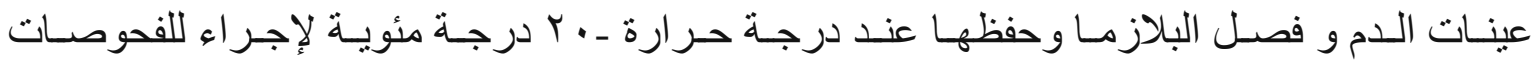
البيو كيميائية.

النتائج: أظهرت النتائج في جميع المجموعات زيـادة ملحوظة في مستويات الليبتين و الريزيستين في البلازما بالمقارنة مع مجمو عة المقارنة الطبيعية، كما حدث إنخفاض ملحوظ في مستويات الأديبونكتين

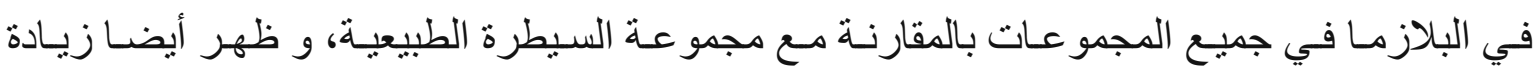
ملحوظـة في نسبة الليبتين إلى الأديبونكتين في جميع المجمو عـات بالمقارنـة مـع مجموعـة المقارنـة الطبيعبة.

الإستنتاج: إنخفاض مستويات الأدييونكتين و زيـادة مستويات الليبتين و الريزيستين في البلازمـا يمكن أن ترجع إلى زيادة نسب الجلوكوز في الدم وإرتفاع مقاومة الإنسولين التي حدثت في الجرذان الجين البدينة، و الجرذان المصابة بالبول السكري و الجرذان البدينة المصابة بالبول السكري. 